\title{
Role of Chitin for Harbouring of Toxigenic Vibrio cholerae O1 El Tor in Aquatic Environment
}

\author{
M Mahmud Hasan ${ }^{1}$, Sucharit Basu Neogi², Iqbal Kabir Jahid², M Sirajul Islam² and Anwara Begum ${ }^{3 *}$ \\ ${ }^{1}$ DNA Division, National Institute of Biotechnology (NIB), Ganakbari, Savar, Dhaka 1349, Bangladesh, ${ }^{2}$ Laboratory Science Division (LSD), \\ International Centre for Diarrhoeal Diseases \& Research, Bangladesh (ICDDR,B), Mohakhali, Dhaka 1212, Bangladesh, ${ }^{3}$ Department of Zoology, \\ University of Dhaka, Dhaka 1000, Bangladesh
}

[Received 09 December 2007; Accepted 14 June 2008]

\begin{abstract}
Vibrio cholerae, the etiological agent of cholera is an autochthonous bacterium of aquatic environment, often found attached to crustacean zooplankton. Chitin is the main component of crustacean exoskeleton, an insoluble polysaccharide. $V$. cholerae can secrete chitinase enzymes, which can facilitate the bacterium's association with chitinous aquatic organisms to utilize it as a potential nutrient source. In the present study, we checked the role of chitin for long term survival of $V$. cholerae. Laboratory based microcosms were prepared with purified artificial chitin chips and a toxigenic strain of $V$. cholerae $\mathrm{O} 1 \mathrm{El}$ Tor. In the presence of chitin, $V$. cholerae was found in a higher cellular density for $>\mathbf{6 1}$ days in culturable condition than control water. We observed that the older chitin chips gradually thinner which indicated that $V$. cholerae utilized chitin. PCR experiment confirmed the presence of the bacterium's cholera toxin coding gene (ctxA) and membrane associated virulent gene ompU remained unaltered. Finally, from randomly amplified polymorphic DNA (RAPD) analysis no significant genotypic variation was detected in the bacterium's genome after its long time association with chitin.
\end{abstract}

Keywords: Vibrio cholerae, Chitin, Polymerase chain reaction (PCR), Microcosm

\section{Introduction}

Cholera is acute, potentially epidemic and life-threatening secretory diarrhoea characterized by voluminous watery stools. The causative agent of cholera is Vibrio cholerae, a Gram-negative motile bacterium, is a natural inhabitant of aquatic ecosystem ${ }^{1}$. Out of more than 200 known serogroups of the bacterium, only the $\mathrm{O} 1$ and $\mathrm{O} 139$ serogroups have been found to be associated with epidemic cholera. Cholera is endemic or epidemic in areas with poor sanitation, it occurs sporadically or as limited outbreaks in developed countries.

Chitin is an insoluble linear $\beta$-1, 4-linked polymer of $N$-acetyl Dglucosamine (GlcNAc) and is the second most abundant polymer after cellulose in nature. This polysaccharide is particularly an important nutrient source for maintaining the ecosystem in the aquatic environment ${ }^{2}$. Each year, 100 billion tons of discarded crustacean shell sink through the world's oceans - more than a billion tons of this have been moulted by copepods alone $e^{3}$, the rest from shrimp, crabs and multitudes of other crustaceans and some diatoms, which are spread over wide geographic and spatial ranges in rivers, estuaries and oceans ${ }^{4}$. A major component of these shells is chitin. In aquatic environment Vibrio cholerae may persist in association with chitinous exoskeleton of aquatic crustacean copepods ${ }^{5-8}$ as well as other aquatic crab $^{9}$, shrimp ${ }^{10}$ and prawn ${ }^{11}$. Many Vibrio species are able to use chitin as a sole carbon and nitrogen source ${ }^{1}$. Marine bacteria including V. cholerae possess complex signal transduction systems for finding chitin, adhering to chitinaceous substrata, degrading it to oligosaccharides, transporting the oligosaccharides to the cytoplasm, and catabolizing the transport products to fructose6-P, acetate and $\mathrm{NH}_{3}{ }^{3}$.

In the present investigation, we prepared microcosm with natural water, artificial chitin chips and inoculated V. cholerae to observe their growth on chitin chips. Toxigenic $V$. cholerae is extremely difficult to isolate from the aquatic sources and generally not found through out the year except cholera seasons. Moreover there is no quantitative estimation of $V$. cholerae survival on artificial chitin chips that can be used as bait to detect toxigenic $V$. cholerae in the environment. Recently, scientists have discovered that $c t x$ is basically a part of genome of phase called ctxö and is a transmissible element in aquatic environment. Therefore, we also observed whether during their long term association with chitin $V$. cholerae do not loose its toxigenic gene $c t x$ and whether there is any major change in their genome by molecular techniques.

*Corresponding author:

Dr. Anwara Begum, Professor, Department of Zoology, University of Dhaka, Dhaka 1000, Bangladesh

Tel (Office): (02) 9661920-73, Ext 7606; Fax: +880 (02) 8615513; E-mail: zooldu@citechco.net 


\section{Materials \& Methods}

\section{Collection of strain}

A recently isolated strain of Vibrio cholerae O1 El Tor (1780) from culture collection of Environmental Microbiology Laboratory of ICDDR,B was used in this study. Identification of the strain was confirmed by a series of biochemical tests and serotyping ${ }^{12}$. After confirmation biochemically and serologically, remaining portion of the isolated colony was streaked onto a gelatin agar (GA) plate and grown overnight at $37^{\circ} \mathrm{C}$ to get a pure culture.

\section{Sources and preparation of water}

The natural fresh water for microcosm preparation was collected from Dhonagodha River (a branch of Meghna River) of Matlab, a cholera endemic area of Bangladesh. The river water was then filtered through $0.22 \mu \mathrm{m}$ Millipore filter and used to the microcosm.

\section{Preparation of microcosms}

Laboratory microcosms were prepared consisting of a natural water [with $\mathrm{pH} 7.7$, temperature $25^{\circ} \mathrm{C}$, salinity $0.1 \mathrm{ppt}$, dissolved oxygen (DO) $6.96 \mathrm{mg} / \mathrm{l}$, total dry solid (TDS) $55.5 \mathrm{mg} / \mathrm{l}$ and conductivity $116.8 \mu \mathrm{S} / \mathrm{cm}$ ] in Erlenmeyer flasks. Erlenmeyer flasks $(500 \mathrm{ml})$ were cleaned with acid hydrochloride and rinsed 10 times with double-distilled, deionized water. For each microcosm experiment the selective strain of V. cholerae O1 El Tor (1780) was added in two separate Erlenmeyer flasks, each of which contains $200 \mathrm{ml}$ of stock water at room temperature. In the first flask of this setup $200 \mathrm{ml}$ of the stock water was used as control water and in the second flask 12 pieces of autoclaved artificial chitin chips (each of which $1 \mathrm{~g}$ in weight) were added.

\section{Preparation of inoculum}

A loopful growth of fresh cultured $V$. cholerae $\mathrm{O} 1 \mathrm{El}$ Tor from the GA plate was re-suspended in LB brought and incubate at $37^{\circ} \mathrm{C}$ for about $6 \mathrm{~h}$. The $90 \%$ transmittance of the suspension at $585 \mathrm{~nm}$ wave length was measured with spectrophotometer and the number of cells per ml had been assessed by using drop plate method as described by Hoben and Somasegoran ${ }^{13}$ to ensure about $10^{7}$ colony forming unit (CFU)/ml. Then a ten-fold dilution was prepared by using phosphate buffer saline (PBS) $\mathrm{pH}$ 8.4. Then $2 \mathrm{ml}$ of diluted inoculum (PBS) of $V$. cholerae O1 El Tor was added by a pipette in each microcosm flask so that the final concentration of the strain would be $10^{4} \mathrm{CFU} / \mathrm{ml}$ in each microcosm and then monitoring the number of $\mathrm{V}$. cholerae $\mathrm{O} 1$ by bacteriological culture method.

\section{Processing of samples}

Samples processing were started within 5 min after added the inoculum and this was considered as 'zero hour' sampling or reading. Subsequently, sampling was carried out at different time intervals ( $0 \mathrm{~h}, 4^{\text {th }} \mathrm{h}, 8^{\text {th }} \mathrm{h}, 24^{\text {th }} \mathrm{h}$ ( $1^{\text {st }}$ day), $2^{\text {nd }}$ day, $4^{\text {th }}$ day, $8^{\text {th }}$ day, $15^{\text {th }}$ day, $25^{\text {th }}$ day, $40^{\text {th }}$ day and $61^{\text {st }}$ day) until all the chitin chips were fully finished. Three types of samples were examined, water from the control flask (CW), chitin chips (CC) and surrounding water of chitin chips (MW). Water $(100 \mathrm{ml})$ was taken from CW and MW in separate Eppendorf tube by separate micropipette and one chitin chip was taken in a Petri dish and homogenized with $2 \mathrm{ml}$ PBS. A series of ten fold dilutions were prepared separately for each sample by PBS. The dilutions were properly mixed by a vortexer and $25 \mathrm{ml}$ portion from each serial dilution were inoculated onto 2 to 3 TTGA plates in a duplicate fashion, using drop plate technique and incubated at $37^{\circ} \mathrm{C}$ for $18-24 \mathrm{~h}$ for counting of the colonies of $V$. cholerae $\mathrm{O} 1$.

\section{Counting procedure for Vibrio cholerae 01}

After incubation, one colony from the resulted growth in each plate was tested by serological methods ${ }^{12}$ for confirmation of the serotype. Bacterial counts were derived from the counts of individual colony and were expressed as colony forming unit (CFU)/ml or g. The arithmetic mean was calculated from the colony counts of duplicate plates.

\section{DNA isolation}

A single colony from pure culture of each sample was taken in $300 \mathrm{ml}$ of autoclaved deionized water containing Eppendorf tube and mixed vigorously. Then the samples were subsequently heated in boiling water for $10 \mathrm{~min}$. The samples were then cooled in ice for $10 \mathrm{~min}$ and followed by centrifuged at $12,000 \mathrm{rpm}$ for $1 \mathrm{~min}$. The supernatants were used as template for the RAPD and PCR of ctxA and ompU genes.

\section{PCR assay for ctxA gene}

Selected primers and PCR conditions for $c t x A$ gene according to Singh et al. ${ }^{14}$ were forward 5'-CGGGCAGATTCTAGACCTCCTG-3', reverse 5'-CGATGATCTTGGAGCATTCCCAC-3'. PCR amplification of the target DNA was carried out in a thermal cycler with a reaction mixture volume of $25 \mu \mathrm{l}$. Each of the reaction mixtures contained $2.5 \mu \mathrm{l}$ of 10x PCR amplification buffer (Invitrogen, USA), $1.0 \mu \mathrm{l}$ of $\mathrm{MgCl}_{2}(50 \mathrm{mM}), 1 \mu \mathrm{l}$ each of $10 \mathrm{mM}$ dNTP (Invitrogen, USA), $1.5 \mu \mathrm{l}$ each of the forward and reverse primers for ctxA, $0.25 \mu \mathrm{l}$ of Taq DNA polymerase at $5 \mathrm{U} / \mu \mathrm{l}$ (Invitrogen, USA), and Milli-Q water to a final volume of $23.5 \mu \mathrm{l}$, and $1.5 \mu \mathrm{l}$ of cell lysate (template DNA). PCR condition was as follows: an initial denaturation at $94^{\circ} \mathrm{C}$ for $5 \mathrm{~min}$, followed by 35 cycles consisting of $94^{\circ} \mathrm{C}$ for $1 \mathrm{~min}$ (denaturation), $60^{\circ} \mathrm{C}$ for $1 \mathrm{~min}$ (primer annealing), and $72^{\circ} \mathrm{C}$ for 1 min (chain extension), and a final extension at $72^{\circ} \mathrm{C}$ for $10 \mathrm{~min}$.

\section{PCR assay for ompU gene}

Selected primers and PCR conditions for ompU gene ${ }^{14}$ were forward 5'-ACGCTGACGGAATCAACCAAAG-3', reverse 5'-GCGGAAGTTTGGCTTG AAGTAG-3'. PCR amplification of the target DNA was carried out in a thermal cycler with a reaction mixture volume of $25 \mu$ l. Each of the reaction mixtures contained $2.5 \mu \mathrm{l}$ of 10x PCR amplification buffer (Invitrogen, USA), $1.5 \mu \mathrm{l}$ of $\mathrm{MgCl}_{2}(50 \mathrm{mM}), 1 \mu \mathrm{l}$ each of $10 \mathrm{mM}$ dNTP (Invitrogen, USA), $1.0 \mu \mathrm{l}$ each of the forward and reverse primers for ompU, $0.25 \mu$ l of Taq DNA polymerase at $5 \mathrm{U} / \mu \mathrm{l}$ (Invitrogen, USA), and Milli-Q water to a final volume of $24 \mu \mathrm{l}$, and $1.0 \mu \mathrm{l}$ of cell lysate (template DNA). 
PCR condition was as follows: an initial denaturation at $95^{\circ} \mathrm{C}$ for $5 \mathrm{~min}$, followed by 35 cycles consisting of $94^{\circ} \mathrm{C}$ for $1 \mathrm{~min} 20 \mathrm{sec}$ (denaturation), $60^{\circ} \mathrm{C}$ for $1 \mathrm{~min} 20 \mathrm{sec}$ (primer annealing), and $72^{\circ} \mathrm{C}$ for $2 \mathrm{~min}$ (chain extension), and a final extension at $72^{\circ} \mathrm{C}$ for 10 min. Amplified gene detection by agarose gel electrophoresis were detected described elsewhere ${ }^{14}$.

\section{Randomly amplified polymorphic DNA (RAPD)}

Primer 5'-AACGCGCAAC-3' was selected for RAPD analyses of the inoculated $V$. cholerae $\mathrm{O} 1$ strain at different time intervals of microcosms. PCR amplification of the target DNA was carried out in a thermal cycler with a reaction mixture volume of $25 \mu \mathrm{l}$. Each of the reaction mixtures contained $2.5 \mu \mathrm{l}$ of 10x PCR amplification buffer (Invitrogen, USA), $1.5 \mu \mathrm{l}$ of $\mathrm{MgCl}_{2}(50 \mathrm{mM}), 2.5 \mu \mathrm{l}$ each of $10 \mathrm{~m} M \mathrm{dNTP}$ (Invitrogen, USA), $2.0 \mu \mathrm{l}$ of the universal random primer, $0.25 \mu \mathrm{l}$ of Taq DNA polymerase at $5 \mathrm{U} / \mu \mathrm{l}$ (Invitrogen, USA), and Milli-Q water to a final volume of $24 \mu \mathrm{l}$, and $1.0 \mu \mathrm{l}$ of cell lysate (template DNA). PCR was programmed as follows: an initial denaturation at $95^{\circ} \mathrm{C}$ for $5 \mathrm{~min}$, followed by 45 cycles consisting of $94^{\circ} \mathrm{C}$ for $1 \mathrm{~min} 30 \mathrm{sec}$ (denaturation), $36^{\circ} \mathrm{C}$ for $1 \mathrm{~min} 30 \mathrm{sec}$ (primer annealing), and $72^{\circ} \mathrm{C}$ for $2 \mathrm{~min} 30 \mathrm{sec}$ (chain extension), and a final extension at $72^{\circ} \mathrm{C}$ for $7 \mathrm{~min}$. The amplification of the desired polymorphic DNA through RAPD was examined by resolving the RAPD product in $2 \%$ agarose gel. During gel electrophoresis a molecular weight marker 100 bp (HaeIII digested Øx174 RF DNA, Gibco-BRL, USA) was used as standards to compare the amplicon size of the PCR products.

\section{Results and Discussion}

Cholera is a dreadful diarrhoeal disease from the time immemorial in Bangladesh and other countries of the world. Vibrio cholerae is considered as most frightening agent that causes cholera globally. This global impact occurs since $V$. cholerae has been regarded as a member of a group of organisms whose major habitats are aquatic ecosystem ${ }^{15-17}$. V. cholerae is free-living in surfaces of freshwater, oceanic and estuarine environment. In aquatic environment it may persist in associations with chitinous exoskeleton of aquatic crustacean copepods ${ }^{5}$, crabs $^{9}$, prawns ${ }^{11}$, shrimps ${ }^{10}$ and lobsters. Through this aquatic environment $V$. cholerae take the opportunity to flash out all over the world and threatening the different human communities.

The results of the microcosm study were observed at different time intervals until the chitin chips were completely finished by the bacteria. Microcosms were protected from any kind of aerobic or other contaminations and then carefully observed the number of $V$. cholerae $\mathrm{O} 1$ by direct culturable count. The result of cultarable counts (Table 1 ) clearly showed that initially V. cholerae O1 could not attach chitin chips but after a few hours they begin to attach with chitin. In the $2^{\text {nd }}$ and $4^{\text {th }}$ day cellular density of $V$. cholerae $\mathrm{O} 1$ increased rapidly and their growth rates are comparatively higher than control water and the surrounding water of chitin chips. Initially the artificial chitin chips were hard, insoluble and floating on water but after few days ( $4^{\text {th }}$ day) they begun to sink down under water and soften. Initially, culturabale counts of $V$. cholerae $\mathrm{O} 1$ were increased rapidly which may be due to the fact that some dissolved nutrients were present within the filtered river water of both microcosm but when the nutrient was finished then bacterial density of the water decreased slowly. On the $8^{\text {th }}$ day the number of $V$. cholerae $\mathrm{O} 1$ attached to chitin reached the highest position $\left(9.594 \times 10^{6} / \mathrm{g}\right)$ than other two water sources and on the $8^{\text {th }}$ day the cultarable count of control water as well as surrounding water of chitin began to decrease. On the $15^{\text {th }}, 25^{\text {th }}$ and $40^{\text {th }}$ day the observation showed that the result of cultarable counts of chitin were still highest in comparison to other two sources and it was also observed that the culturable counts of $V$. cholerae $\mathrm{O} 1$ from surrounding water of chitin (MW) were higher than control water (CW). A possible reason was that after $15^{\text {th }}$ day the chitin chips were dissolved in the water (MW) because of bacterial enzymatic action and thus some chitinous nutrients were present in dissolved condition in the surrounding water of chitin (MW). On the $15^{\text {th }}, 25^{\text {th }}, 40^{\text {th }}$ and $61^{\text {st }}$ day a dense layer of bacterial biofilm was found in each piece of chitin chips which completely coated them. On the $61^{\text {st }}$ day the last piece of the chitin chip, control water and the water surrounding of chitin chips were processed and the result showed that cultarable V. cholerae $\mathrm{O} 1$ were still present only within the chitin chip (CC) but absent in control water (CW) and the water surrounding of chitin chips (MW). It was also observed that the cultarable counts of $V$. cholerae $\mathrm{O} 1$ found from chitin chip on the $61^{\text {st }}$ day were higher than the inoculums, which were added to the microcosms at the initial stage of the experiment (0-hour reading).

Table1. Direct counts of culturable Vibrio cholerae O1 at different time intervals of microcosms

\begin{tabular}{lccc}
\hline Time interval & \multicolumn{3}{c}{ Count of culturable Vibrio cholerae O1 } \\
\cline { 2 - 4 } & $\begin{array}{c}\text { Control water } \\
(\mathrm{CFU} / \mathrm{ml})\end{array}$ & $\begin{array}{c}\text { Microcosm water } \\
(\mathrm{CFU} / \mathrm{ml})\end{array}$ & $\begin{array}{c}\text { Chitin chips } \\
(\mathrm{CFU} / \mathrm{g})\end{array}$ \\
\hline $0 \mathrm{~h}$ & $2.93 \times 10^{3}$ & $2.877 \times 10^{3}$ & $\mathrm{Nil}$ \\
$4 \mathrm{~h}$ & $1.274 \times 10^{4}$ & $4.466 \times 10^{3}$ & $2.95 \times 10^{2}$ \\
$8 \mathrm{~h}$ & $1.122 \times 10^{4}$ & $1.096 \times 10^{4}$ & $2.39 \times 10^{2}$ \\
$24 \mathrm{~h}$ & $3.953 \times 10^{5}$ & $5.357 \times 10^{5}$ & $2.999 \times 10^{2}$ \\
$2^{\text {nd }}$ day & $5.211 \times 10^{6}$ & $6.637 \times 10^{6}$ & $7.947 \times 10^{4}$ \\
$4^{\text {th }}$ day & $5.395 \times 10^{6}$ & $2.754 \times 10^{6}$ & $8.729 \times 10^{5}$ \\
$8^{\text {th }}$ day & $2.6 \times 10^{6}$ & $1.757 \times 10^{6}$ & $9.594 \times 10^{6}$ \\
$15^{\text {th }}$ day & $1.22 \times 10^{3}$ & $5.236 \times 10^{5}$ & $8.871 \times 10^{6}$ \\
$2^{\text {th }}$ day & 29.99 & $5.47 \times 10^{5}$ & $1.548 \times 10^{7}$ \\
$4^{\text {th }}$ day & 1.3 & $1.279 \times 10^{4}$ & $5.508 \times 10^{6}$ \\
$61^{\text {st }}$ day & $\mathrm{Nil}$ & $\mathrm{Nil}$ & $7.194 \times 10^{4}$ \\
\hline
\end{tabular}

The result of polymerase chain reaction (PCR), targeting the $c t x A$ and ompU genes were obtained from gel electrophoresis (Figure 1 and 2 respectively) the amplicon size for ctxA gene and ompU gene were 564 bp and 869 bp respectively. It was observed that toxigenic genes ( $c t x A$ and ompU) were present in the experimental strain of $V$. cholerae $\mathrm{O} 1 \mathrm{El}$ Tor and there were no significant changes occurred of these genes. The result of RAPD (Figure 3) showed that there were no significant genotypic changes occurred 
within the polymorphic DNA sequences of the bacterium's genome, collected from different (nutritional condition and time intervals) microcosms. So from this result of cultarable counts of $V$. cholerae $\mathrm{O} 1$ of the microcosm experiment it is clear that chitin play a great role as a source of nutrient, which increase the survival potentiality $V$. cholerae $\mathrm{O} 1$ in normal aquatic condition without affecting their toxin producing gene as well as their genotypes and the present findings of microcosm experiment exhibits similarity with that of the previous respected studies ${ }^{5-8}$.

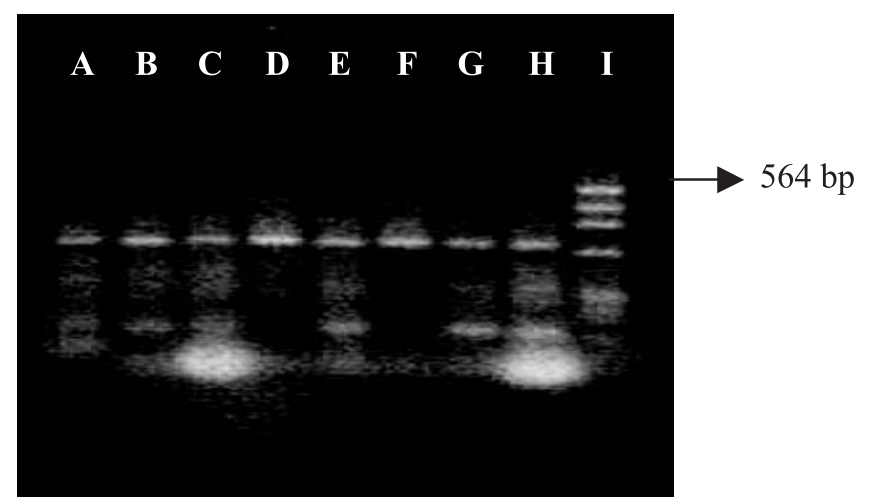

Figure 1. Agarose gel electrophoresis of ctxA PCR product. $C W=$ Control water; $M W=$ Microcosm water; Lane A: CW-0-h, Lane B: $C W 40^{\text {th }}$ day, Lane C: $M W-0-h$, Lane D: $M W 40^{\text {th }}$ day, Lane E: CC $8^{\text {th }} h$, Lane F: $15^{\text {th }}$ day, Lane G: CC $40^{\text {th }}$ day, Lane H: $61^{\text {st }}$ day, and Lane I = Marker DNA.

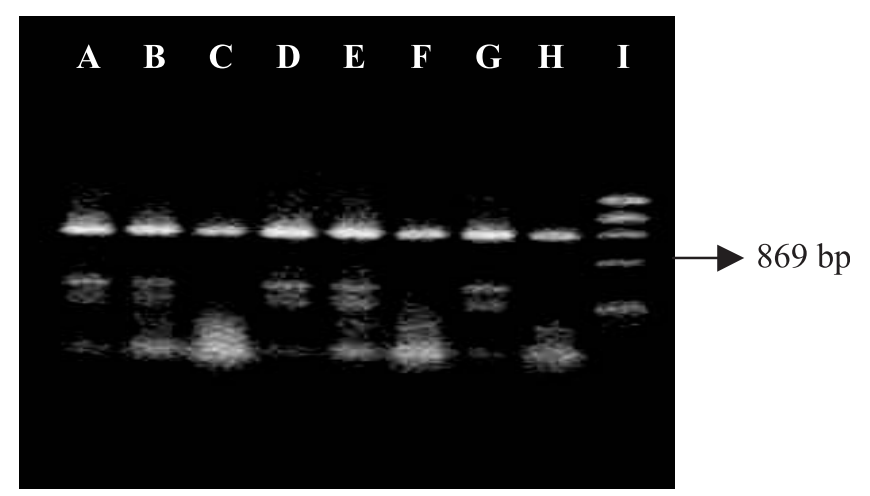

Figure 2. Agarose gel electrophoresis of ompU PCR product. $C W=$ Control water $; M W=$ Microcosm water; Lane A: CW-0-h, Lane B: CW 40 th day, Lane C: MW-0-h, Lane D: $M W 40^{\text {th }}$ day, Lane E: CC $8^{\text {th }}$ h, Lane F: $15^{\text {th }}$ day, Lane G: CC $40^{\text {th }}$ day, Lane H: $61^{\text {st }}$ day, and Lane I: Marker DNA.

Several researchers thought that chitin is a principal component for reservoir of $V$. cholerae and hence they tried to prove that the relationships between $V$. cholerae and chitin by different artificial condition such as mutation on various chitinase gene ${ }^{18}$, changing the $\mathrm{pH}^{19}$, or temperature ${ }^{20}$, and isolation, characterization, molecular cloning and sequencing ${ }^{21-23}$ of different types of chitinase genes from several Vibrio spp. including V. cholerae. Most of the research was conducted by using liquid chitin but in

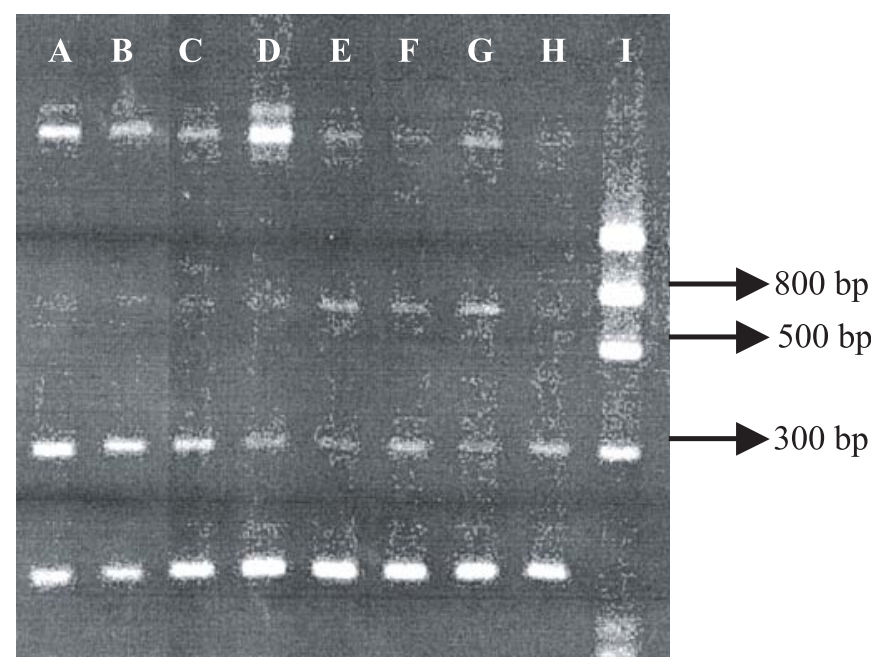

Figure 3. Agarose gel electrophoresis of RAPD PCR product. $C W=$ Control water; $M W=$ Microcosm water; Lane A: CW-0-h, Lane B: $C W 40^{\text {th }}$ day, Lane C: $M W-0-h$, Lane D: $M W 40^{\text {th }}$ day, Lane E: CC $8^{\text {th }} h$, Lane F: $15^{\text {th }}$ day, Lane G: CC $40^{\text {th }}$ day, Lane H: $61^{\text {st }}$ day, and Lane I: Marker DNA.

the present study solid artificial chitin chips were used. The result of microcosm experiment in the present study showed that $V$. cholerae could utilize chitin chips as their potential nutrient in a simpler way in normal aquatic condition.

\section{References}

1. Colwell RR \& Spira WM. 1992. The ecology of Vibrio cholerae. In Cholera (Barua D \& Greenough III WB eds), pp 107-127. Plenum Medical Book Co, New York.

2. Gooday GW. 1990. The ecology of chitin degradation. Adv Microb Ecol. 11: 387-430.

3. Keyhani NO \& Roseman S. 1999. Physiological aspects of chitin catabolism in marine bacteria. Biochim Biophys Acta. 1473: 108122.

4. Douglas H, Bartlet T \& Farooq A. 2005. Chitin, cholera, and competence. Science. 310: 1775-1777.

5. Huq A, Small EB, West PA, Huq MI, Rahman R. \& Colwell RR. 1983. Ecological relationship between Vibrio cholerae and planktonic crustacean copepods. Appl Environ Microbiol. 45: 275-283.

6. Huq A, West PA, Small EB, Huq MI \& Colwell RR. 1984. Influence of water temperature, salinity, and $\mathrm{pH}$ on survival and growth of toxigenic Vibrio cholerae serovar $\mathrm{O} 1$ associated with live copepods in laboratory microcosm. Appl Environ Microbiol. 48(2): 420-424.

7. Chiavelli DA, Marsh JW \& Taylor RK. 2001. The mannose-sensitive hemagglutinin of Vibrio cholerae promotes adherence to zooplankton. Appl Environ Microbiol. 67(7): 3220-3225.

8. Araujo DB, Martins SC, Albuquerque LM \& Hofer E. 1996. Influence of the copepod Mesocyclops longisetus (Crustacea: Cyclopidae) on the survival of Vibrio cholerae O1 in fresh water. Cad Saude Publica. 12(4): 551-554.

9. Huq A, Huq SA, Grimes DJ, O’Brien M, Chu KH, Capuzzo JM \& Colwell RR. 1986. Colonization of the gut of the blue crab (Callinectes sapidus) by Vibrio cholerae. Appl Environ Microbiol. 52(3): 586-588.

10. Dalsgaard A, Echeverria P, Larson JL, Siebeling R, Serichantatergs O \& Huss HH. 1995. Application of ribotyping for differentiation Vibrio cholerae non-O1 isolated from shrimp farms in Thailand. Appl Environ Microbiol. 61: 245-251. 
11. Faming D, Shimodori S, Moriya T, Iwanaga S \& Amako K. 1993. Purification and characterization of a protein cryoprotective for Vibrio cholerae extracted from the prawn shell surface. Microbiol Immunol. 37(11): 861-868.

12. Hoben HJ \& Somasegoran P. 1982. Comparison of the pour, spread and drop plate method for enumeration of Rhizobium spp. in inoculants made from prestilized peat. Appl Environ Microbiol. 44: 12421247.

13. Colwell RR, Huq A, Chowdhury MAR, Bryton PR \& Xu B. 1995. Serogroup conversion of Vibrio cholerae. Can J Microbiol. 41: 946950.

14. Singh DV, Isac SR \& Colwel RR. 2002. Development of a hexaplex PCR assay for rapid detection of virulence and regulatory genes in Vibrio cholerae and Vibrio mimicus. J Clin Microbiol. 40: 43214324.

15. Colwell RR. 1996. Global climate and infectious disease: The cholera paradigm. Science. 274: 2025-2031.

16. Islam MS, Drasar BS \& Sack RB. 1993. The aquatic environment as reservoir of Vibrio cholerae: A review. J Diarr Dis Res. 11: 197-206.

17. Islam MS, Hasan MK, Miah MA, Qadri F, Yunus M, Sack RB \& Albert MJ. 1993. Isolation of Vibrio cholerae O139 Bengal from water in Bangladesh. Lancet. 342: 430.
18. Li X \& Roseman S. 2004. The chitinolytic cascade in vibrios is regulated by chitin oligosaccharides and a two-component chitin catabolic sensor/kinase. Proc Natl Acad Sci USA. 101(2): 627-631.

19. Kaneko T \& Colwell RR. 1975. Adsorption of Vibrio parahaemolyticus onto chitin and copepods. Appl Microbiol. 29: 269-274.

20. Amako K, Shimodori S, Imoto T, Miake S \& Umeda A. 1987. Effects of chitin and its soluble derivatives on survival of Vibrio cholerae $\mathrm{O} 1$ at low temperature. Appl Environ Microbiol. 53: 603-605.

21. Suginta W, Vongsuwan A, Songsiriritthigul C, Prinz H, Estibeiro P, Duncan RR, Svasti J, Fothergil L \& Gilmore LA. 2004. An endochitinase A from Vibrio carchariae: Cloning, expression, mass and sequence analyses, and chitin hydrolysis. Arch Biochem Biophys. 424(2): 171180.

22. Meibom KL, Li XB, Nielsen AT, Wu CY, Roseman S \& Schoolnik GK. 2004. The Vibrio cholerae chitin utilization program. Proc Nat Acad Sci USA. 101(8): 2524-2529.

23. Bendt A, Huller H, Kammel U, Helmke E \& Schweder T. 2001. Cloning, expression, and characterization of a chitinase gene from the Antarctic psychrotolerant bacterium Vibrio sp. strain Fi:7. Extremophiles. 5(2): 119-126. 